\title{
Trade Liberalisation Could Improve Producers Profitability in Agriculture: A Case of Basmati Rice
}

\author{
Muhammad Zulfiqar, Dilawar Khan, Anwar F. Chishti, Munir Khan, \\ WASIULLAH, AJMAL WAHEED, MUHAMMAD ZAKIR and ROBINA KaRIM
}

\section{INTRODUCTION}

Rice is one of the most important crops of Pakistan having second position as staple food after wheat [Akhtar (1999)] while Basmati rice is an important export commodity [Pakistan (2008)]. Basmati rice is the third largest crop in terms of occupying area under cultivation [Zulfiqar (2008)]. Due to the importance of Basmati rice to the economy of Pakistan, this piece of research has been conducted with the objectives to; (i) identify various protection policies and interventions made to Basmati rice economy in Pakistan (ii) estimate welfare effects associated with existing protection policies and interventions and (iii) to estimate implications of WTO's trade liberalisation in domestic economy and abroad.

Production of various crops including Basmati rice has been a private job. However, marketing and trade of most of the commodities have mainly been regulated or managed by government in one or the other way. The major policy intervention of Government of Pakistan has been in the form of 'support prices', currently abandoned to comply with World Trade Organisation (WTO) agreements. The announcement of 'support or procurement prices' and size of stocks procured thereof have affected production and trade of the commodities involved. Secondly, State Trading Enterprises (STEs) had been playing major role in trading of some major agricultural commodities including Basmati rice. Although lately Pakistan has taken certain measures to liberalise trade but still according to Trading Corporation of Pakistan (2006) it is, inter alia, involved in inspection of export purpose rice. Thirdly, import tariffs and export duty has been important interventions. According to Scott, et al. (1990), imposition of export duties on Basmati rice has been a common feature. Some clues of such policies in Basmati rice economy are also found in studies like Cornelisse and Kuijpers (1987), Ahmad, et al. (1987), Hamid, et al. (1987), Chishti (1994), Ackerman and Dixit (1999), Ashfaq, Griffith, and Parton (2001) and Arifullah (2007).

Muhammad Zulfiqar<zulfi64@yahoo.com> is Director Planning, Kohat University of Science and Technology, Kohat. Dilawar Khan <dilawarmkd@yahoo.com> is Assistant Professor, Kohat University of Science and Technology, Kohat. Anwar F. Chishti <chishti_anwar@yahoo.com> is Incharge Graduate Programme, Muhammad Ali Jinnah University, Islamabad. Munir Khan <munirkhan4@hotmail.com> is Professor, NWFP Agricultural University, Peshawar. Wasiullah <wasiullahmalik_63@yahoo.com> is Project Director, Kohat University of Science and Technology, Kohat. Ajmal Waheed <awkhan2@yahoo.com> is Assistant Professor, Quaid-i-Azam University, Islamabad. Muhammad Zakir <mzakirs@yahoo.com> is Director QEC, Kohat University of Science and Technology, Kohat. Robina Karim < robikarim@yahoo.com> is PhD Fellow, NWFP Agricultural University, Peshawar. 
For the instant article, types of interventions that Government of Pakistan has adopted to regulate its Basmati rice economy from 1985 to 2005, our study period, have been determined through reviewing Pakistan's Basmati rice domestic wholesale price, export price and world trade price. An examination of the data on prices (Table 1) reflects that Pakistan's domestic wholesale price $\left(P_{d}\right)$ has remained, on average, at US\$374.89 (Pak Rs 13777.29) per M. ton while average world trade price $\left(P_{w}\right)$ remained US $\$ 332.97$ (Rs 12236.59) per M. ton. However, Pakistan's average export price $\left(P_{e}\right)$ was US\$514.23 (Rs 18897.74), signifying export tax amounting US\$139.34 (Rs 5120.71) per M. ton during the 1985-2005 study period. Basmati is especial quality rice and its export can not be evaluated on the basis of world average rice price given in Table 1. Therefore free trade export price has been estimated using domestic price of Basmati rice and establish whether Pakistan has supported its Basmati rice in the domestic market. For this purpose export supply $\left(E_{s}\right)$ and export demand $\left(E_{d}\right)$ functions adopted from Zulfiqar (2008) and solved for Basmati rice free trade export price $\left(P_{e f}\right)$. So realised free trade export price along with Pakistan's domestic Basmati rice price is reflected in Table 2. A comparison of the two prices $\left(P_{d} \& P_{e f}\right)$ indicates Basmati Rice remained under 'price tax-cum-export tax' regime.

\section{METHODOLOGICAL/ANALYTIC FRAMEWORK}

The objective set for this research required to engage three methodologies, namely: (a) analysis of prices using time series data from 1985 to 2005 and identification of government interventions which was done through calculating mean values of prices for the study period. (b) computation of associated welfare effects in terms of changes in producer and consumer surpluses $(\triangle P S \& \triangle C S)$ using following approach.

$$
\Delta P S=+/-\int_{P d / P f}^{P d / P f} S(P) d p
$$

or

$$
\Delta C S=+/-\int_{P d / P f}^{P d / P f} D(P) d p
$$

and (c) analysing implications of implementation of WTO's Agreements particularly agreement on Agriculture from the difference of domestic and world prices. As WTO in general aims at introducing and implementing free trade. For estimating welfare effects of existing policy regimes, we compared those with free trade situation. In case no government interventions were existed, free trade price $P_{d f}$ would have prevailed instead of existing domestic price $P_{d}$. Hence, the effects of implementation of free trade at domestic level have been estimated using free trade scenario. However, at international level, these estimates have been developed using an increase in the prices at international market, based on empirical results of a number of studies such as FAO (2005), Anderson, Martin, and Mensbrugghe (2006) and Akhtar (1999). The functional detail of these methodologies are given in their respective sections in succeeding sections.

\section{Identification of Government Interventions}

To achieve our objectives, the study period (1985-2005) was divided into two subperiods: pre-WTO (1985-1995) and post-WTO (1995-2005). The mean values of prices for the two sub-periods were computed, as follows, using Tables 1 and 2. 
Table 1

\begin{tabular}{lcc}
\hline & $\begin{array}{c}\text { Pre-WTO Period } \\
(1985-1995)\end{array}$ & $\begin{array}{c}\text { Post-WTO Period } \\
(1995-2005)\end{array}$ \\
\hline Pakistan's Wholesale Price $\left(\mathrm{P}_{\mathrm{d}}\right)$ & US\$368.18 (Rs 8262.30) & US\$381.61(Rs 19292.28) \\
Estimated Free Trade Price $\left(\mathrm{P}_{\mathrm{e}}\right)$ & US\$398.63 (Rs 8945.57) & US\$387.79 (Rs 19604.86) \\
Pakistan's Trade Price $\left(\mathrm{P}_{\mathrm{e}}\right)$ & US\$551.94 (Rs 12385.92) & US\$476.52 (Rs 24090.51) \\
\hline
\end{tabular}

Average $\mathrm{P}_{\mathrm{d}}$ lingered at US\$368.18 per $\mathrm{M}$. ton against average $\mathrm{P}_{\mathrm{e}}$ at US\$551.94 and average $P_{e f}$ at US\$398.63 during the pre-WTO period, reflecting 'price tax-cum-export tax' regime (Figure 1). Post-WTO study period witnessed average $P_{d}$ (US\$381.61), $P_{e}$ (US\$476.52) and $P_{\text {ef }}$ (US\$387.79), again reflecting 'price tax-cum-export tax' regime (Figure 2).

\section{Computation of Welfare Effects}

Welfare effects of (pre- and post-WTO) scenarios, were estimated using simple welfare analysis. To conduct welfare analysis, producer and consumer surpluses ( $\triangle \mathrm{PS}$ and $\triangle \mathrm{CS}$ ) were determined along with computed export tax (ET) based on demand, supply and price linkage equations. To estimate producer and consumer surplus and to estimate these equations, time series data from 1985 to 2005 was used.

Pre-WTO Situation: The welfare effects of 'price tax-cum-export tax' regime of pre-WTO period are represented in Figure 1, as follows.

Fig. 1. Price Tax-cum-export Tax Regime during Pre-WTO 10 Years

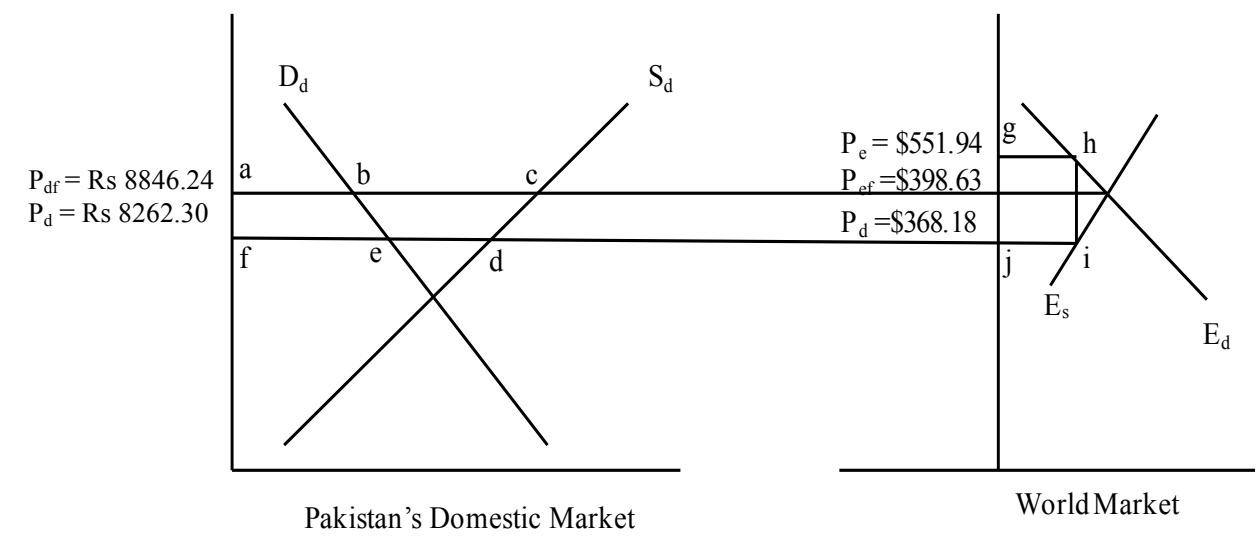

The associated welfare effects were captured using the following model.

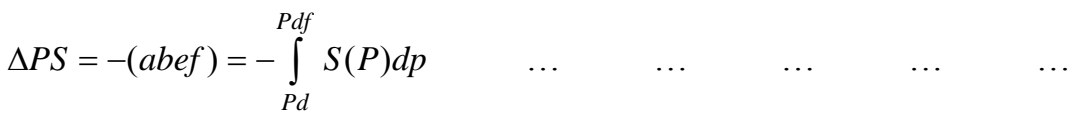

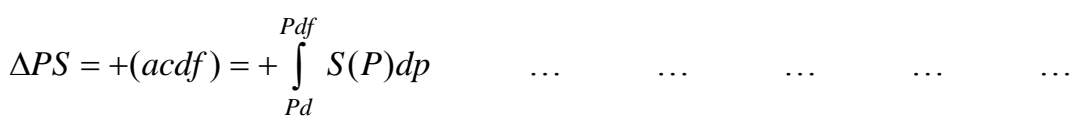


$E T=($ ghij $)=\left(\begin{array}{llllll}\left(P_{e}-P_{d}\right) E_{s} \text { (export supplies) } & \ldots & \ldots & \ldots & \ldots & \text { (3) }\end{array}\right.$

$N W G / C$ (net welfare gain or cost $)=\Delta P S+\triangle C S+E T \quad \ldots \quad \ldots \quad$ (4)

The model adopted following Basmati rice supply and demand functions from Zulfiqar (2008).

$$
\begin{aligned}
& \begin{array}{llllllll}
S_{d}=676.9517+0.052582 P_{d} & \ldots & \ldots & \ldots & \ldots & \ldots & (5)
\end{array} \\
& \begin{array}{llllllll}
D_{d}=840.7971-0.008451 P_{d} & \ldots & \ldots & \ldots & \ldots & \ldots & \text { (6) }
\end{array} \\
& \begin{array}{llllllll}
E_{s}=-163.845+0.061033 P_{d} & \ldots & \ldots & \ldots & \ldots & \ldots & (7)
\end{array} \\
& \begin{array}{lllllllll}
E_{d}=468.7365-0.23247 P_{e} & \ldots & \ldots & \ldots & \ldots & \ldots & (8)
\end{array} \\
& \begin{array}{lllllll}
=1.360216+1.1063 P_{w} & \ldots & \ldots & \ldots & \ldots & (9)
\end{array}
\end{aligned}
$$

For arriving at free market price $\left(P_{e f}\right)$, export supply $\left(E_{s}\right)$ and export demand $\left(E_{d}\right)$ were equalised, as follows.

$\begin{array}{lllllllll}E_{s}=E_{d} & \ldots & \ldots & \ldots & \ldots & \ldots & \ldots & \ldots & \ldots(10 \mathrm{a})\end{array}$

Since $P_{d} / E X R=P_{e}$ or $P_{d}=P_{e}{ }^{*} E X R$, replacing $P_{d}$ in above equation we obtained:

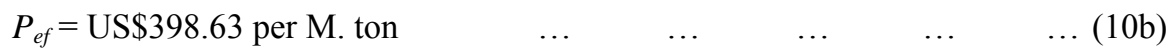

Putting values of $P_{e f}=398.63$ given in (10b) in $E_{d}$ in Equation (8)

$E_{\mathrm{df}}=468.7365-0.23247\left(P_{e}=398.63\right) \quad \ldots \quad \ldots \quad \ldots \quad \ldots$ (11a)

$\begin{array}{lllllll}E_{\text {df }}=575.85 \mathrm{M} \text {. tons } & \ldots & \ldots & \ldots & \ldots & \ldots & \ldots \text { (11b) }\end{array}$

$\begin{array}{llllllll}\text { Equating } E_{d f}=E_{s f} & \ldots & \ldots & \ldots & \ldots & \ldots & \ldots \text { (12a) }\end{array}$

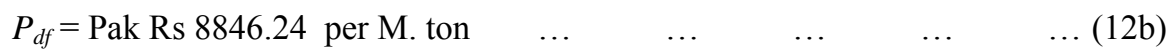

After computing $P_{e f}$ and $P_{d f}$ in Equations (10b) and (12b), the pre-WTO scenario's welfare effects specified in model (1) to (4) were estimated, as follows.

$$
\begin{aligned}
& \Delta P S=-\left\{\int_{P d=8262}^{P d f=8846.24}(676.9517+0.052582 P d) d p\right\} \quad \ldots \quad \ldots \quad \ldots \text { (13a) } \\
& =-\left\{676.9517 P d+\left(\frac{0.052582}{2}\right) P d^{2}\right\} /{ }_{6315.20}^{8846.24} \\
& =-\left\{\left\{676.9517(8846.24)+\left(\left(\frac{0.052582}{2}\right)(8846.24)^{2}\right)\right\}-\right. \\
& \left.\left\{676.9517(8262.30)+\left(\left(\frac{0.052582}{2}\right)(8262.30)^{2}\right)\right\}\right\} \\
& =- \text { Rs } 657953 \text { thousand } \\
& \Delta C S=+(\text { acdf })=\int_{P d=8262.30}^{P d f=8846.24}(840.7971-0.008451 P d) d p \quad \ldots \quad \ldots \text { (14a) }
\end{aligned}
$$




$$
\begin{aligned}
& =\text { Rs } 448759.20 \text { thousand } \\
& \begin{array}{lllllll}
=\text { Rs } 448.76 \text { million } & \ldots & \ldots & \ldots & \ldots & \ldots
\end{array} \\
& E T=(\text { ghij })=\left(\begin{array}{lllllll}
\left(P_{e}-P_{d}\right) E_{s} & \ldots & \ldots & \ldots & \ldots & \ldots & \ldots \text { (15a) }
\end{array}\right. \\
& =\text { US } \$ 62555.42 \\
& =\text { Rs } 1403792 \text { thousand }
\end{aligned}
$$

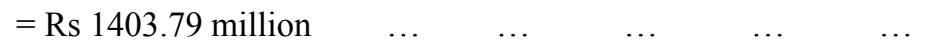

$$
\begin{aligned}
& N W G / C=\triangle P S+\triangle C S+E T \\
& \begin{array}{lll} 
& \cdots & \cdots
\end{array} \quad \ldots
\end{aligned}
$$

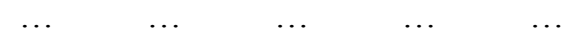

Post-WTO Situation: Figure 2 given below best reflects the interventions made in Basmati rice economy during second part of the study period.

Fig. 2. Price Tax-cum-export Tax Regime during Post-WTO 10 Years

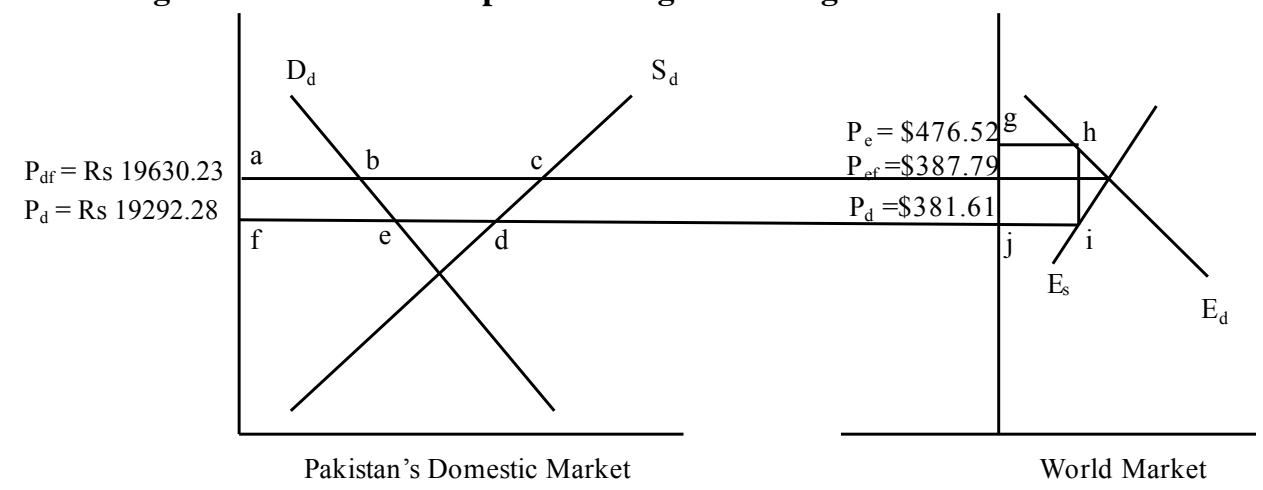

The following supply and demand functions adopted from Zulfiqar (2008) was used for the post-WTO period (1995-2005).

$$
\begin{aligned}
& \begin{array}{llllllll}
S_{d}=898.4736+0.052582 P_{d} & \ldots & \ldots & \ldots & \ldots & \ldots & (17)
\end{array} \\
& \begin{array}{llllllll}
D_{d}=1437.392-0.008451 P_{d} & \ldots & \ldots & \ldots & \ldots & \ldots & (18)
\end{array} \\
& \begin{array}{llllllll}
E_{s}=-538.919+0.061033 P_{d} & \ldots & \ldots & \ldots & \ldots & \ldots & (19)
\end{array} \\
& \begin{array}{llllllll}
E_{d}=749.3228-0.23247 P_{e} & \ldots & \ldots & \ldots & \ldots & \ldots & (20)
\end{array} \\
& \begin{array}{llllllll} 
& 298.5887+1.1063 P_{w} & \ldots & \ldots & \ldots & \ldots & \ldots & (21)
\end{array}
\end{aligned}
$$

For estimation of free market price $\left(P_{e f}\right)$

$\begin{array}{lllllllll}E_{s}=E_{d} & \ldots & \ldots & \ldots & \ldots & \ldots & \ldots & \ldots & \ldots(22 \mathrm{a})\end{array}$

Since $P_{d} / E X R=P_{e}$ or $P_{d}=P_{e}{ }^{*} E X R$, replacing $P_{d}$ in above equation we get:

$\begin{array}{llllllll}P_{e f} & =\mathrm{US} \$ 387.79 \text { per M. ton } & \ldots & \ldots & \ldots & \ldots & \ldots & (22 \mathrm{~b})\end{array}$

Putting values of $P_{e f}=387.79$ given in (22b) in $E_{d}(20)$

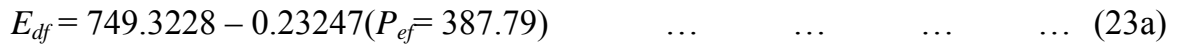


$\begin{array}{llllllll}E_{\text {df }}=659.17 \text { M. tons } & \ldots & \ldots & \ldots & \ldots & \ldots & \ldots & (23 b)\end{array}$

$\begin{array}{llllllll}\text { Equating } E_{d f}=E_{s f} & \ldots & \ldots & \ldots & \ldots & \ldots & \ldots & (24 \mathrm{a})\end{array}$

$\begin{array}{lllllll}P_{d f}=\text { Rs } 19630.23 \text { per M. ton } & \ldots & \ldots & \ldots & \ldots & \ldots & (24 b)\end{array}$

For estimation of $N S W G / C$ specified in model (1) to (4), we estimate various components of $N W G / C$, as follows.

$$
\begin{aligned}
& \Delta P S=-\left\{\int_{P d=19292.28}^{P d f=19630.23}(898.4736+0.052582 P d) d p\right\} \quad \ldots \quad \ldots \quad \ldots \quad \text { (25a) } \\
& =- \text { Rs } 649480.00 \text { thousand }
\end{aligned}
$$

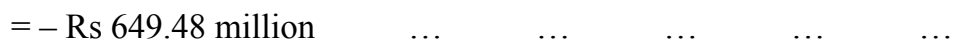

$$
\begin{aligned}
& \Delta P S=-\left\{\int_{P d=19292.28}^{P d f=19630.23}(1437.392-0.008451 P d) d p\right\} \quad \ldots \quad \ldots \quad \ldots \text { (26a) } \\
& =\text { Rs } 430193.50 \text { thousand } \\
& \begin{array}{llllll}
\text { R Rs } 430.19 \text { million } & \ldots & \ldots & \ldots & \ldots & \ldots
\end{array} \\
& E T=(\text { ghij })=\left(\begin{array}{lllllll}
\left.P_{e}-P_{d}\right) E_{s} & \ldots & \ldots & \ldots & \ldots & \ldots & \ldots \text { (27a) }
\end{array}\right. \\
& =\text { US } \$ 60604.84 \\
& =\text { Rs } 3063899.00 \text { thousand } \\
& \begin{array}{llllllll}
\text { R Rs } 3063.90 \text { million } & \ldots & \ldots & \ldots & \ldots & \ldots & \ldots \text { (27b) }
\end{array}
\end{aligned}
$$

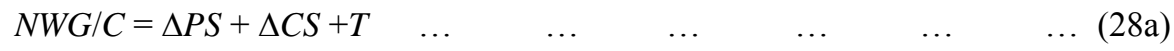

$$
\begin{aligned}
& =\text { Rs } 2844612 \text { thousand } \\
& =\text { Rs } 2844.61 \text { million }
\end{aligned}
$$

Implications of WTO's Trade Liberalisation in Domestic Economy: WTO's Agreements particularly agreement on Agriculture aims at steadily reducing 'domestic support', 'import tariffs' and 'export subsidies' and eliminate/abolish all such protection/support policies over a specified period (www.wto.org). This means that WTO in general aims at introducing and implementing free trade. So, if no government interventions were existed, free trade price $P_{d f}=$ Rs 8846.24 would have prevailed instead of existing domestic price $P_{d}=$ Rs 8262.30 per metric ton during the pre-WTO period (Figure 1). The effects of implementation of free trade would have been as follows.

$$
\begin{array}{lllllll}
\triangle P S=\text { Rs } 657.95 \text { million } & \ldots & \ldots & \ldots & \ldots & \ldots & (29) \\
\triangle C S=- \text { Rs } 448.76 \text { million } & \ldots & \ldots & \ldots & \ldots & \ldots & (30) \\
E T(\operatorname{export} \text { tax })=- \text { Rs } 1403.79 \text { million } & \ldots & \ldots & \ldots & \ldots & (31) \\
N W G / C=- \text { Rs } 1194.60 \text { million } & \ldots & \ldots & \ldots & \ldots & \ldots & (32)
\end{array}
$$

Similarly, welfare effects of free-trade scenario for post-WTO period would have been, as follows.

$$
\begin{aligned}
& \begin{array}{lllllll}
\triangle P S & =\text { Rs } 649.48 \text { million } & \ldots & \ldots & \ldots & \ldots & \ldots
\end{array}
\end{aligned}
$$

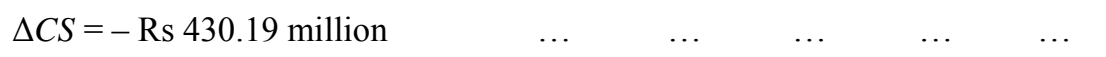


$\begin{array}{llllllll}E T=- \text { Rs } 3063.90 \text { million } & \ldots & \ldots & \ldots & \ldots & \ldots & (35)\end{array}$

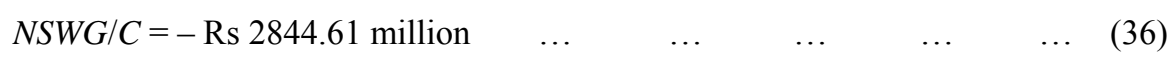

Implementation of WTO Trade Liberalisation in International Markets:

Certain empirical studies have suggested that implementation of Agreement on Agriculture and other WTO agreements would raise world prices. FAO (2005) and Akhtar (1999) have found that impacts of trade liberalisation on world commodity prices would be positive. Another study by Anderson, Martin and Mensbrugghe (2006) found that a move to free trade would increase farm employment, the real value of agricultural output and exports, real returns to farm land and unskilled labour, and real net farm incomes in developing countries. In want of exact estimates, an assumption a 5 percent rise in world prices $\left(P_{w}\right)$ was made and examined its effects on Pakistan's domestic economy.

\section{Pre-WTO Scenario}

Using Equation (9) and putting 5 percent-enhanced value of $P_{w}$, that is, $1.05 P_{w}$

$$
\begin{aligned}
& E_{d}=1.360216+1.1063\left(P_{w}=355.6407\right) \quad \ldots \quad \ldots \quad \ldots \quad \ldots \text { (37a) }
\end{aligned}
$$

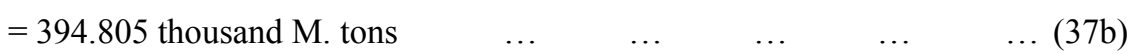

Equating $E_{d}=394.805$ with $E_{s}$ given in (7) and solving for $P_{d}$

$$
\begin{aligned}
& \begin{array}{lllllllll}
E_{d}=E_{s} & \ldots & \ldots & \ldots & \ldots & \ldots & \ldots & \ldots & \ldots \text { (38a) }
\end{array} \\
& 394.81=-163.845+0.061033 P_{d} \\
& \begin{array}{lllllll}
P_{d}=9153.253 & \text { Rs per M. ton } & \ldots & \ldots & \ldots & \ldots & \ldots
\end{array}
\end{aligned}
$$

Substituting $P_{d}=9153.253$ in (5 and 6) and solving for $S_{d}$ and $D_{d}$

$$
\begin{aligned}
& \begin{array}{lllllll}
S_{d}=676.9517+0.052582 P_{d} & \ldots & \ldots & \ldots & \ldots & \ldots & \text { (39a) }
\end{array}
\end{aligned}
$$

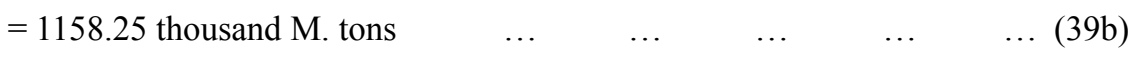

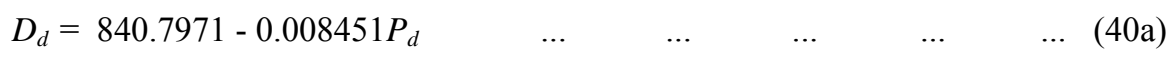

$$
\begin{aligned}
& \begin{array}{lllllll}
=763.44 \text { thousand } \mathrm{M} \text {. tons } & \ldots & \ldots & \ldots & \ldots & \ldots(40 \mathrm{~b})
\end{array}
\end{aligned}
$$

\section{Welfare Effects}

Welfare effects of the changes in Pakistan's Basmati rice domestic price from the existing level of $P_{d 0}=$ Rs 8262.30 due to new level of $P_{d f}=$ Rs 9153.252 are measured in terms of changes in producers and consumers surpluses ( $\triangle P S$ and $\triangle C S$ ), using the following model.

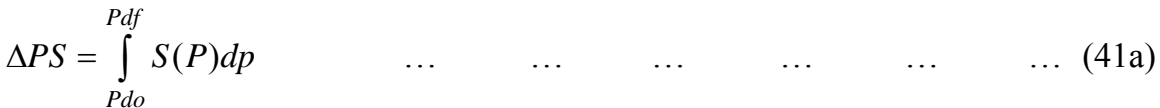

$$
\begin{aligned}
& =\int_{P d o=8262.30}^{P d f=9153.253}(676.9517+0.052582) d p \\
& \begin{array}{lllllll}
=\text { Rs } 1011.08 \text { million } & \ldots & \ldots & \ldots & \ldots & \ldots & \ldots \text { (41b) }
\end{array}
\end{aligned}
$$




$$
\begin{array}{lcccccc}
\Delta C S=-\int_{P d o=8262.30}^{P d f=9153.253}(840.7971-0.008451) d p & \ldots & \ldots & \ldots \text { (42a) } \\
=- \text { Rs } 683.55 \text { million } & \ldots & \ldots & \ldots & \ldots & \ldots & \ldots \text { (42b) } \\
N W G / C=\Delta P S+\triangle P S & \ldots & \ldots & \ldots & \ldots & \ldots & \ldots \text { (43a) } \\
=1011.08-683.55 & & & & & & \\
=\text { Rs } 327.53 \text { million } & \ldots & \ldots & \ldots & \ldots & \ldots & \ldots \text { (43b) }
\end{array}
$$

Post-WTO Scenario: In the foregoing fashion, 5 percent-enhanced world price $P_{w}$ would cause domestic price to rise from the existing level of $P_{d 0}=$ Rs 19292.28 to new level of $P_{d f}=$ Rs 19950.35 and the associated welfare effects would be measured as:

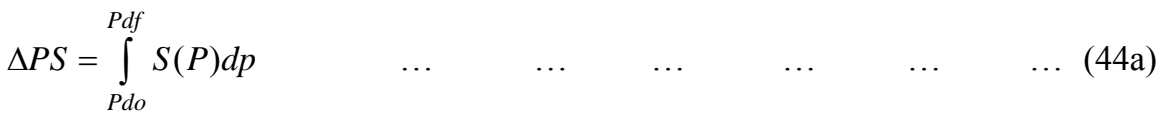

$$
\begin{aligned}
& =\int_{P d o=19292.28}^{P d f=19950.35}((898.4736+0.052582 P d) d p \\
& \begin{array}{lllllll}
=\text { Rs.1270.216 million } & \ldots & \ldots & \ldots & \ldots & \ldots & \ldots \text { (44b) }
\end{array} \\
& \Delta C S=-\int_{P d o=19292.28}^{P d f=19950.35}(1437.392-0.008451 P d) d p \quad \ldots \quad \ldots \quad \ldots \text { (45a) } \\
& \begin{array}{lllllll}
=- \text { Rs } 836.7886 \text { million } & \ldots & \ldots & \ldots & \ldots & \ldots & \ldots \text { (45b) }
\end{array} \\
& \begin{array}{lllllll}
N W G / C=\triangle P S+\triangle P S & \ldots & \ldots & \ldots & \ldots & \ldots & \ldots \text { (46a) }
\end{array} \\
& =1270.216-736.7886 \\
& \begin{array}{lllllll}
=\text { Rs } 433.4274 \text { million } & \ldots & \ldots & \ldots & \ldots & \ldots & \ldots \text { (46b) }
\end{array}
\end{aligned}
$$

\section{RESULTS AND DISCUSSION}

The domestic Basmati rice price (US\$368.18 per M.ton) was kept lower than the Pakistan average export price (US\$551.94 per M.ton). Thus producers suffered losses in their producer surpluses by Rs 657.95 million per year. The government collected Rs 1403.79 million per year as export tax during pre-WTO period. Although, consumers benefited by Rs 448.76 million per year in their consumer surpluses but losses to producers were greater than benefits to consumers. However, due to export tax earnings, overall benefit of Rs 1194.60 million per year was estimated for the society.

There has been an increase in domestic prices during post-WTO period (1995$2005)$ to (US $\$ 381.61$ per M.ton). But average export prices were (US\$476.52 per M.ton), that again resulted in losses to producers of Rs 649.48 million per year. The consumers' surplus stood at Rs 430.19 million per year while export tax collected was Rs 3063.90 million. Losses in Producers' surplus were larger than benefit to consumers' surplus but net welfare benefit was Rs 2844.61 million per year mainly due to export tax.

The interventions in Basmati rice economy resulted in net welfare gain in both, pre- and post-WTO periods due to export tax collection. Such a scenario obscured real welfare of producers and consumers. As export tax would minimise/abolish in free trade situation and producers and consumers' surpluses would remain for a comparative evaluation of welfare effects. Therefore, from trade liberalisation perspective, the study 
reveals that losses to producers surplus had been greater than benefits in consumers' surplus due to government interventions and if trade liberalisation was introduced in the domestic economy, it would have incurred greater gains to Basmati rice producers than losses to consumers. The results show similar trend for international market i.e. trade liberalisation in world Basmati rice markets would have been benefited Pakistan's economy by Rs 327.53 million and Rs 433.43 million per annum during pre- and postWTO periods respectively.

\section{CONCLUSION AND RECOMMENDATIONS}

The foregoing results and discussions are concluded and recommendations thereof are as under.

(1) It seems that government policy interventions in price regime have lowered during post-WTO period as compared to pre-WTO period. This is evident from relatively narrowing gaps between Pakistan's domestic price and export price of former period than that of pre-WTO period. The positive trend of narrowing gap between domestic and export (international) prices needs to be continued till international prices prevail at domestic level that will improve the profitability of producers.

(2) The estimated welfare effects in terms of producers and consumers' surpluses revealed heavier losses than gains during both the periods but relatively lesser losses during post-WTO period. Trade liberalisation simulations for domestic economy revealed larger producers' gains relative to losses to consumers if trade was liberalised. Thus, Pakistan should continue implementing trade liberalisation in line with WTO regime.

(3) Trade liberalisation simulations for world market also reflected higher gains to the domestic economy of Pakistan. Therefore efforts should be geared up for trade liberalisation on global basis.

(4) Instead of coddling in State Trading Enterprises (STEs), the government should act as facilitator of trade as envisaged in the 'Green Box' of Agreement on Agriculture and other WTO agreements. It should concentrate on research, development and out-reach related investments for improvement in productivity and quality of Basmati rice. 
Annex Table 1

Pakistan’s Basmati Rice Prices for 1985-05 (Prices per Million Ton)

\begin{tabular}{|c|c|c|c|c|}
\hline \multirow[b]{2}{*}{ Year } & \multicolumn{2}{|c|}{ Pakistan's Domestic Wholesale Price } & \multirow{2}{*}{$\begin{array}{c}\text { World Price } \\
\text { (US\$) }\end{array}$} & \multirow{2}{*}{$\begin{array}{c}\text { Pakistan's Export Price } \\
\text { (US\$) }\end{array}$} \\
\hline & Pak Rs & US\$ & & \\
\hline $1985-86$ & 6300.75 & 390.40 & 268.23 & 655.87 \\
\hline $1986-87$ & 6625.75 & 385.68 & 280.56 & 697.68 \\
\hline $1987-88$ & 6843.75 & 388.86 & 347.59 & 713.10 \\
\hline $1988-89$ & 6625.25 & 344.79 & 351.99 & 677.51 \\
\hline $1989-90$ & 7326.00 & 341.61 & 356.24 & 671.57 \\
\hline $1990-91$ & 8314.50 & 370.81 & 368.93 & 466.23 \\
\hline $1991-92$ & 9338.25 & 375.87 & 358.03 & 407.07 \\
\hline $1992-93$ & 10323.00 & 397.65 & 332.35 & 424.34 \\
\hline $1993-94$ & 10650.50 & 353.09 & 374.17 & 405.56 \\
\hline $1994-95$ & 10275.25 & 333.05 & 348.97 & 400.45 \\
\hline $1995-96$ & 14316.75 & 426.49 & 403.33 & 406.71 \\
\hline $1996-97$ & 14729.25 & 377.74 & 390.74 & 440.67 \\
\hline $1997-98$ & 17683.25 & 409.37 & 351.67 & 452.41 \\
\hline 1998-99 & 20570.75 & 439.64 & 329.25 & 508.14 \\
\hline $1999-00$ & 15902.00 & 307.16 & 295.98 & 501.71 \\
\hline $2000-01$ & 18140.25 & 310.42 & 268.52 & 463.95 \\
\hline 2001-02 & 21000.50 & 341.88 & 252.40 & 461.93 \\
\hline $2002-03$ & 23327.75 & 398.77 & 276.89 & 494.78 \\
\hline 2003-04 & 22636.25 & 393.16 & 325.24 & 508.54 \\
\hline 2004-05 & 24616.00 & 411.43 & 378.35 & 526.34 \\
\hline Average & 13777.29 & 374.89 & 332.97 & 514.23 \\
\hline
\end{tabular}

Source: FAO (www.fao.org; Statistical databases).

Agricultural Statistic of Pakistan (Various Issues).

Annex Table 2

Pakistan's Basmati Rice Domestic and Estimated Free Trade Prices for 1985-05 (Prices per Million Ton)

\begin{tabular}{lcc}
\hline Year & $\begin{array}{c}\text { Pakistan's Domestic Wholesale Price } \\
\text { (US\$) }\end{array}$ & $\begin{array}{c}\text { Basmati Rice Estimated Free Export } \\
\text { Trade Price (US\$) }\end{array}$ \\
\hline $1985-86$ & 390.40 & 441.09 \\
$1986-87$ & 385.68 & 442.30 \\
$1987-88$ & 388.86 & 446.55 \\
$1988-89$ & 344.79 & 399.83 \\
$1989-90$ & 341.61 & 391.38 \\
$1990-91$ & 370.81 & 384.66 \\
$1991-92$ & 375.87 & 380.02 \\
$1992-93$ & 397.65 & 401.07 \\
$1993-94$ & 353.09 & 358.97 \\
$1994-95$ & 333.05 & 340.46 \\
$1995-96$ & 426.49 & 424.48 \\
$1996-97$ & 377.74 & 383.34 \\
$1997-98$ & 409.37 & 412.86 \\
$1998-99$ & 439.64 & 444.79 \\
$1999-00$ & 307.16 & 320.49 \\
$2000-01$ & 310.42 & 319.81 \\
$2001-02$ & 341.88 & 348.89 \\
$2002-03$ & 398.77 & 404.64 \\
$2003-04$ & 393.16 & 400.32 \\
$2004-05$ & 411.43 & 418.31 \\
Average & 374.89 & 393.21 \\
\hline Source: Agricultural Statistics of Pakistan (Various Issues)
\end{tabular}

Source: Agricultural Statistics of Pakistan (Various Issues). 


\section{REFERENCES}

Ackerman, K. Z. and P. M. Dixit (1999) An Introduction to State Trading in Agriculture. Market and Trade Economics Division, Economic Research Service, U.S. Department of Agriculture. (Agricultural Economic Report No. 783).

Ackerman, K. Z. and P. M. Dixit (1999) An Introduction to State Trading in Agriculture. Market and Trade Economics Division, Economic Research Service, U.S. Department of Agriculture. (Agricultural Economic Report No. 783).

Ahmad, B. and A. M. Chaudary (1987) Profitability of Pakistan's Agriculture. In B. A. Azhar (ed.) (1996) Pakistan Agricultural Economics-A Book of Readings. Islamabad: National Book Foundation.

Ahmad, B. and A. M. Chaudhry (1987) Profitability of Pakistan's Agriculture. In B. A. Azhar (ed.) (1996) Pakistan Agricultural Economics-A Book of Readings. Islamabad: National Book Foundation.

Akhtar, M. R. (1999) Effects of Trade Liberalisation on Agriculture in Pakistan: Commodity Aspects. The Regional Coordination Centre for Research and Development of Coarse Grains, Pulses, Roots and Tuber Crops in the Humid Tropics of Asia and the Pacific (CGPRT Centre), Bogor Indonesia. (Working Paper 44).

Anderson, K., W. Martin, and D. V. D. Mensbrugghe (2006) Incidence of Trade and Subsidies Policies on Developing Countries Welfare, Export and Debt Sustainability. The World Bank, Washington, DC.

Arifullah, S. (2007) Pakistan's Crop Sector: An Economic Analysis. PhD Thesis, Department of Agricultural Economics, NWFP Agricultural University Peshawar, Pakistan.

Ashfaq, M., G. Griffith, and K. Parton (2001) Welfare Effects of Government Interventions in the Wheat Economy of Pakistan. Agricultural Prices Commission Pakistan Journal of Agricultural Economics 4:1, 25-33.

Chishti, A. F. (1994) An Evaluation of Pakistan's Rice Trade Policy: A Case Study of Basmati Rice. PhD Thesis, University of Illinois at Urbana-Champaign, USA.

Cornelisse, P. and B. Kuijpers (1987) A Policy Model of the Wheat and Rice Economy of Pakistan. The Pakistan Development Review 25:4, 365-399.

FAO (2005) The State of Food and Agriculture: Agricultural Trade and Poverty. Food and Agriculture Organisation of the United Nations, Rome. (FAO Agriculture Series No. 36).

Hamid, et al. (1987) The Wheat Economy of Pakistan: Setting and Prospects. USAID/International Food Policy Research Institute, Washington, DC. (Mimeographed).

Hamid, et al. (1987) The Wheat Economy of Pakistan: Setting and Prospects (Mimgiraphed). USAID/International Food Policy Research Institute, Washington, DC.

Pakistan, Government of (2008) Economic Survey of Pakistan. Islamabad: Ministry of Finance, Economic Adviser's Wing, Finance Division.

Pakistan, Government of (Various Issues) Agricultural Statistics of Pakistan. Islamabad: Ministry of Food, Agriculture and Livestock.

Scott, W. E., A. K. Siddiqi, S. A. William, and M. I. Muhammad (1990) Export Restrictions-A Study of Restrictions on Agricultural Exports in Pakistan. Ministry 
of Food, Agriculture and Cooperatives, and United States Agency for International Development. Islamabad. (Special Report No. 17).

Trading Corporation of Pakistan (2006) 38th Annual Report 2004-05. Available at: www.pakistan.gov.pk.

Zulfiqar, M. (2008) WTO's Trade Liberalisation: Implications for Pakistan's Crop Sector. PhD Thesis submitted to Department of Agricultural Economics, NWFP Agricultural University Peshawar. 